\title{
'At the back of my ear’: A Note on Seamus Heaney and Scottish Poetry
}

\author{
Marco Fazzini
}

I first came across Heaney's name when I was doing a research on the English poet Geoffrey Hill for my degree dissertation at the University of Venice in the middle 1980s. Only a few articles on Hill had been published at that time; one of them was by Seamus Heaney. So, while working on a great English poet, I discovered a great Irish poet. His seminal collection Preoccupations: Selected Prose 1968-1978 showed me what a refined and deep reader of other poets (Wordsworth, Yeats, Hopkins, MacDiarmid, Larkin, Hughes, Hill and Kavanagh) Heaney could be. It also revealed his versatility and broad range of interests. Summarising the intentions and achievements of such an extensive cultural contribution is both difficult and daunting: there was the Heaney who was fascinated with Brodsky, Milosz and Herbert, as well as the classicist Heaney, a companion to Sophocles, Dante and Virgil; Heaney the poet and winner of the Nobel Prize for Literature in 1995; Heaney the translator of Anglo-Saxon and Scots poetry, of the Irish legend of Sweeney or of Leon Janacek; and Heaney the teacher at the Queen's University of Belfast, at the Carysfort College, and at Harvard as Boylston Professor of Rhetoric and Oratory (for this reason, dividing his life between the Republic of Ireland, where he moved in 1972, and the USA, his second home). Then, there is also the poet who refused the title of Poet Laureate because he felt himself to be 'off-centre', both in nationality and language; the poet-intellectual who, refusing to appear in a famous anthology of British poetry, wrote: 'Be advised, my passport's green / No glass of ours was ever raised / To toast the Queen' (Heaney, 1983: 9).

My infatuation with Heaney's poems was immediate. I was so attracted to the bog fragments of his Selected Poems that I at once translated some of them (for the first time) into Italian. The article was published in 1989, soon after my experience with the Geoffrey Hill 
dissertation and translation: those 'bog poems' were published in a literary journal, now defunct, called Origini. It was at that time, and mainly because of the translations, that Heaney and I began exchanging letters and messages. The first letter was dated 15 September, 1989. Heaney appreciated the journal I sent him, and was honoured despite his (as he put it) minute knowledge of Italian. Having a look now at all the papers we exchanged, I realise that more than 25 years have elapsed, and that a folder has been filled with letters, cards, postcards, faxes, slim pamphlets, manuscripts, and greetings cards for Christmas (usually with a fragment of a poem, a quotation, or a phrase).

I remember I was particularly moved by a 1997 pamphlet called 'Would They Had Stayed' which included a poem dedicated to three great poets from Scotland that I knew well: Norman MacCaig, Sorley Maclean and George Mackay Brown. All three poets died in 1996. For Heaney, like for everybody interested in contemporary Scottish literature, this was a great loss. His indebtedness to the XX-century Scottish poetry was evident from the very beginning of his poetic career. Heaney himself pointed to the early influences he felt were shaping him, particularly in reference to Hugh MacDiarmid, MacCaig and, perhaps a bit unexpectedly, the late Medieval poet Robert Henryson and the two Gaelic poets Sorley Maclean and Iain Crichton Smith. It is his concern with those poets, especially in the light of his own critical accounts and poetic practice, that I would like to investigate in this brief essay.

I remember that in 1993, after translating several of Norman MacCaig's poems, I had a chat with Heaney in Bologna. It was after he had launched the Italian translation of his volume Station Island. The poet admitted that he and Norman were close friends, and asked me to keep him informed of my work on MacCaig. In one of his letters, dated 6th February 1995, Heaney wrote: 'I would love to be connected with this enterprise. Norman is a dear friend and I have always wanted to do some salute to him. Never somehow managed it. Anyhow, we'll keep in touch'. Sometime later, he agreed to write an introduction to the book 
entitled L'equilibrista, which included thirty Norman MacCaig poems I had translated as well as a preface by Valerie Gillies and my interview with the poet. The introduction, which contains important references and clues to understanding Heaney's early fascinations and influences, was later re-published, first in the Irish Times after MacCaig's death (in 1996), then in his 2002 collection of essays Finders Keepers.

Heaney introduced MacCaig at the Kilkenny Festival in 1975, but the two had met in St Andrews two years earlier. Heaney recollects: 'My first encounter with Norman MacCaig's poetry converted me to it. In a BBC pamphlet that accompanied Listening and Writing, a Schools Radio series produced in the early 1960s, I came across "Summer Farm" - >>Straws like tame lightnings lie about the grass / And hang zigzag on hedges $<<$ Brilliant. A unique continuum of wiliness and sensuousness. The minimal and the dotty $->>A$ hen stares at nothing with one eye, / Then picks it up $<<-$ transposed into a metaphysical key'. In the next paragraph he adds: 'He was a great fisherman, a master of the cast, of the line that is a lure. And the angler's art - the art of coming in at an angle - is there in his poetry too. He could always get a rise out of the subject. He made it jump beyond itself' (MacCaig, 1995).

One of his images seems particularly relevant to me. Heaney's use of the fisherman's line under the surface of the water hints at the obliqueness of his own technique of in-depth excavation, when it becomes a tool to probe hidden and internal feelings and dreams, either hauled up from the unconscious or taken from history. And history, for Heaney, often means the history of a language or languages, even those lost and forgotten. This is the strategy that he shared with MacCaig, bridging Irish and Scottish traumas and desires. As he himself put it in his essay: 'One day at a party in Edinburgh, in a room full of smoke and music and flirtation, Norman took me into a corner and began to whistle a totally bewitching air. It was a fragment of pibroch, a few orphaned phrases as piercing as curlew-call, but it was also a melody of the soul's loneliness, a tune that was like a piece of secret knowledge... The 
filament of sound that unspooled from his lips that day was an Ariadne's thread leading in to the heart of the Scottish Gaelic maze: in there, at the outback of modernity and English, there dwells the foetal shape of defeat and dispersal, language loss and trauma' (MacCaig 1995: 12$13)$.

When L'equilibrista was finally published in 1995, Heaney, despite a bad cold, wanted to fly to Edinburgh and launch the book together with MacCaig and Valerie Gillies. MacCaig was very frail and unstable due to illness, yet he enjoyed the reading and cherished his friends. Earlier, Heaney had asked me not to show his introduction to MacCaig. Understandably, on the day of the launch, the Scottish poet was deeply moved. I sensed that Seamus was probably thinking that it was the last time he would enjoy Norman's company. I imagine that Heaney's admiration for Norman MacCaig's poetry was mostly determined by Norman's accurate descriptions of the deceitful nature of language when describing the world, but also by the conflict between the English language and the Scottish landscape or, worse, between the English language and the native languages of Scotland, Scots and Gaelic in particular, a problem he could easily link to a similar situation in contemporary Ireland. Unable to enter the final secret of a landscape which suffers the naming imposed by a colonising language, MacCaig's response to the original native way of talking and naming shows his strong sense of dislocation and regret. So, in the attempt to subdue 'the experience to the language, the exotic life to the imported tongue' (Maxwell 1965: 82-3), the English language here inevitably generates the mystery of a double vision. In one of his most famous poems, MacCaig says: 'Who owns this landscape? - / The millionaire who bought it or / the poacher staggering downhill in the early morning / with a deer on his back? // Who possesses this landscape? - / The man who bought it or / I who am possessed by it?' (MacCaig 1990: 225). If the problem of possession and dispossession opens up a series of historical wounds regarding the relationship between Scotland and England, coloniser and colonised - such as 
the tragedy of the Clearances - MacCaig's also gives us an attentive recollection of visual sensations to affirm identity through a politics of loyalty and revenge: 'Or has it come to this, / that this dying landscape belongs / to the dead, the crofters and fighters / and fishermen whose larochs / sink into the bracken / by Loch Assynt and Loch Crocach ? - / to men trampled under the hoofs of sheep / and driven by deer to / the ends of the earth...' (MacCaig 1990: 226). The sense of a disappearing Gaelic society is always present in MacCaig's poetry, as well as the disruptive historical references to the Clearances and their consequences. This country haunted by 'bog-trotters, moss-troopers, / fired ricks and roof-trees in the black night - glinting / on tossed horns and red blades' is the violent starting-point of an inevitable shrinking of Gaelic population and their heritage, an issue Heaney particularly associated with what happened in his home country.

Heaney's interest in the Scottish poetry produced by some of his best friends did not diminish through decades. He not only contributed on MacCaig and later on MacDiarmid, but wrote a decisive essay on Edwin Muir for my Alba Literaria. A History of Scottish Literature (Fazzini, 2005), a piece of writing that had to pass through a series of seemingly unending corrections and drafts. These common friends were very much talked about when we met, be it in St Andrews, Milan, or Mantua. I remember that in one of our meetings, in Dublin in 2008, while we were sipping coffee in his large home kitchen next to the Strand, Seamus and I commented on the demonstrations we participated in the day before at Tara, where he gave a short speech and read a few poems. In those days, trying to support a demonstration for Tara and save that archaeological site from the construction of a devastating highway seemed an appropriate stand on Heaney's side, especially if it might help the survival of a place which had served as Ireland's political and spiritual capital up until the arrival of the Normans. In fact, as the recognized seat of the kings of Ireland until the sixth century, and a key place in Neolithic times, Tara attracted Paul Muldoon and Seamus Heaney in a reunion of intents, 
despite Heaney himself confessed to me to having been somewhat exploited by some newspapers articles and journalists. Yet, Tara on that very day traced the thread of our conversation.

In that afternoon we talked of the English archaeological remains of Offa's period which Heaney appreciated through the partly autobiographical and partly historical reconstruction in Geoffrey Hill's Mercian Hymns - Heaney himself wrote that 'Offa's story makes contemporary landscape and experience live in the rich shadows of a tradition' (Heaney, 1980a: 160); of the bushmen rock paintings he visited when, after visiting NELM and reading and lecturing at Rhodes University (Grahamstown, South Africa) he was accompanied by our common friends, the South African poets Don Maclennan and Dan Wylie, on a special tour to a famous archaeological site - Maclennan himself, in his Rock Paintings at Salem, later wrote: 'My companions / photograph the paintings. / I envisage shiny prints / they'll show to relatives back home. / But how can we enter / this other world / of blood-red figures freed / by healing acts / of which we're ignorant, / by hands on back and chest / that redirect or free / the boiling energy? / Dreaming and waking / intermingle here confusedly.' (Maclennan, 2001: 5); of the other major figure in the South African poetic field, Douglas Livingstone - also of Scottish origins - whom I had known well and whose work I had translated for various publications, a man who devoted his career to recover, thanks to his investigations constructed on water and bush images, the pre-colonial civilization of a forgotten land, when rock art had meant the interlacing of the animal and the human worlds in a natural pre-verbal language of a sort. As Livingstone wrote in his 'Rock Art': 'Times were pitiless, rough. / The code has not changed much. // The series ends with the / beast trampling with its knees / tribesmen in the throes of / worshipping this new god.' (Livingstone 1978: 16)

Livingstone's image is particularly apt because Heaney himself talks of a 'pre-verbal register' of the poetic language when referring to MacDiarmid, one of his favourite 
Olympians. Heaney's attention to and involvement in my translation of MacDiarmid's long poem ‘On a Raised Beach' (MacDiarmid, 2000: 6-9) was probably suggested by my effort to reproduce that 'pre-verbal register' in Italian. As Heaney himself admitted, MacDiarmid had fascinated him since the very beginning of his poetic career and he considered the Whalsay poet 'a far-out blethering genius'. In his celebrated essay 'A Torchlight Procession of One', the Irish poet paid further compliments and described MacDiarmid as the writer who 'prepared the ground for a Scottish literature that would be self-critical and experimental in relation to its own inherited forms and idioms, but one that would also be stimulated by developments elsewhere in world literature' (Heaney, 2002: 294).

Heaney met MacDiarmid for the first time in 1967, in the house of Kader Asmal, professor of Law at the Trinity College and an anti-apartheid activist, just before a poetry reading to celebrate the Human Rights Day. He met the Scottish poet again at his house in Biggar (in Lanarkshire), after having chatted about him with Patrick Crotty, who had written a $\mathrm{PhD}$ dissertation on MacDiarmid (O’Driscoll, 2008: 362-5). It seems that, other than the strength of the first 1922 short Scots lyrics as well as the 1926 long poem 'A Drunk Man Looks at the Thistle', what attracted Heaney to MacDiarmid was the latter's strategic shift from 'synthetic Scots' to 'synthetic English'. Heaney insists: 'MacDiarmid's ambitions are still the right ones. What was great about his effort in Scotland was the inclusiveness of it' (O’Driscoll, 2008: 363). In his poem, 'An Invocation', Heaney calls his Scottish friend a 'catechism worth repeating always' (1996: 28). Earlier, Heaney had addressed MacDiarmid in his first prose book, Preoccupations: Selected Prose 1968-1978 (1980). He dedicated several pages to the Scottish poet in one of his Oxford Lectures (published as The Redress of Poetry: Oxford Lectures, 1995) and mentioned him in Stepping Stones.

On the dust jacket of Scottish Scene, a work by Hugh MacDiarmid and Lewis Grassic Gibbon published in 1934, which was also the year of publication of MacDiarmid's long 
poem, 'On a Raised Beach', a map of Scotland is shown with some of Scotland's poets occupying the territories related to their works and their lives. MacDiarmid himself stands upright on Whalsay in the Shetland Islands, his hands at his sides, and, slightly bent towards the south-west, surveys the Scottish scene while striking an inquisitive posture, probably making sure that the Scottish Renaissance is safely on its course. Heaney may have remembered the map and the long poem when, apparently referring to MacDiarmid's programme for the re-unification of Scotland and Ireland under the driving force of Gaelic, he wrote his invocation: 'Incline to me, MacDiarmid, out of Shetland, / Stone-eyed from stonegazing, sobered up / And thrawn. Not the old vigilante // Of the chimney corner, having us on, / Setting us off, the drinkers' drinker; no, / Incline as the sage of wind that flouts the rock face, // As gull stalled in the seabreeze, gatekeeper / Of open gates behind the brows of birds...'

Many details included in Heaney's poem refer to events, ideas and achievements of some eighty years before when MacDiarmid, aged 41, composed one of the deepest and most stimulating poetic meditations of the last century, 'On a Raised Beach'. Laid low by a psychological and physical distress, MacDiarmid arrived in Whalsay, Shetlands, hoping to regain energies and the will to write. His stay in Whalsay has in itself something of an act of self-preservation; Heaney speaks of MacDiarmid's survival that 'had to do with his getting down to the bedrock of his own resources, a bedrock which was reinforced at the time by contact with the stoical fishermen of the Shetland Islands and his at-homeness in the bleakness of the actual geological conditions' (Heaney, 2002: 305). Thanks to the friendship of Thomas Robertson, the Scottish poet learnt about the glaciation of the islands, the formation of rocks in that part of the world, and the West Linga raised beaches. The story that he spent three days on a beach without food, sleeping in a cave, has the air of myth about it. 
It's more likely that from his cottage in Sodom he enjoyed the view of the Linga Sound and beyond, and of the island's raised beach.

Despite being remote from us in time and place, 'On a Raised Beach' wins the contemporary reader with its steady yet thrilling voice. In the poem, MacDiarmid used his newly created 'synthetic English' and managed to reemphasize the focus of Scottish literature. The long poem, a complex philosophical and poetical vision, is truly unique in its slowly unravelling argument of the precarious balance of the attentive mind and the opaque matter, pushing the reader into unknown areas of conjecture and insight with an intoxicating mix of linguistic fantasies. The poet's investigation is vertical: the ambition is to go as deep as possible into the essence of the physical world, to the very haecceitas of the stones. This is done mainly through the experimental language which reveals its numerous etymological strata and tries to preserve its oral origins or, as Heaney has it, a "phonetic patterning which preceded speech and authenticated it, a kind of pre-verbal register to which the poetic voice had to be tuned' (Heaney, 2002: 301). Incidentally, Heaney is not unanimous in his final evaluation of the long poem. On one hand, he speaks of a 'fine excess' and 'unique multitudinous accuracy and psychedelic richness'; on the other hand, such poems as 'On a Raised Beach' totter 'close to self-parody and only get by through the huge appetite their author displays for matching the multiplicity of the phenomena with a correspondingly cornucopic vocabulary' (Heaney, 2002: 308).

So, what Heaney discovered in MacCaig and MacDiarmid, but also in the other two major contemporary Scottish poets, George Mackay Brown and Sorley Maclean - of the latter he observed that 'He has an epic poet's possession of ground, founders, heroes, battles, lovers, legends, all of them at once part of his personal apparatus of feeling and part of the common but threatened ghost-life of his language and culture... There is nothing antiquarian or archival about this drive. We need only compare the way the names of mountains, waters, ad 
woods animate his poetry with the way the names of places and characters are put to work in the writings of David Jones in order to see how purely poetic, how non-programmatic, how free from the whiff of the scholars midnight oil are the topographical and mythological elements in Maclean's work' (Ross-Hendry 1986: 5) -, was certainly a sense of strong identity rooted in place and dialect.

The same impulse seems to have informed his reading of Robert Henryson, a late XVcentury poet, 'a schoolmaster of Dunfermline'. Heaney's 2009 translation of Henryson's The Testament of Cresseid was a fine culmination of his infatuation with the Scottish matter and it impelled the Irish poet to provide some interesting comments. In his conversation with Daniel O'Driscoll, Heaney pointed to 'a hidden Scotland at the back of my ear, the Ulster Scots idiom I used to hear from County Antrim farmers at the cattle fairs in Ballymena' (O’Driscoll, 2008: 365). Almost the same words are used in the introduction to The Testament of Cresseid and Seven Fables: 'Henryson's language led me back into what might be called "the hidden Scotland" at the back of my own ear. The speech I grew up with in mid-Ulster carried more than a trace of Scottish vocabulary and as a youngster I was familiar with Ulster Scots idioms and pronunciations across the River Bann in County Antrim. I was therefore entirely at home with Henryson's “sound of sense", so much in tune with his note and his pace and his pitch that I developed a strong inclination to hum along with him' (2009: xiii-xiv). Much later the Irish poet came across a British Library exhibition which included an illustrated manuscript of one of Henryson's fables: "I was so taken by the jaunty, canty note of its opening lines that I felt an urge to get it into my own words" (xiii). It is at this point that Heaney provides us with the already-quoted suggestion of the fable's language giving him a sense of the 'hidden Scotland', a trace of the repressed linguistic and topographical identity (the Irish variant of this issue is memorably explored in the poems of Wintering Out). Emphasised by the poet in his introduction to the Henryson translations is his memory of a sudden discovery of intimacy 
with a language whose accents, intonations and even words sounded strangely familiar to him: "the way his [Henryson's] voice is (as he might have put it) "mingit" with the verse forms, the way it can modulate from insinuation to instruction, from high-toned earnestness to wily familiarity - and it was this sensation of intimacy with a speaker at once sober and playful that inspired me to begin putting the not very difficult Scots language of his originals into rhymed stanzas of more immediately accessible English' (viii).

If we go back to what Heaney wrote about his 'sense of place', we should pay attention to both what he observes of poets such as Larkin, Hughes and Hill - who can master their own part of the English landscape and create different 'Englands of the mind' - and to his precise technique of mingling a traditional idea of geography to the oral and aural heritage of a place. (Heaney 1980a: 150-169) In this way, MacCaig's, Maclean's and MacDiarmid's Scottishness, like Heaney's Irishness or Jones's Welshness, is something quite different from a pure idea of a local cultural identity. What Heaney had at the back of his ear was the County Derry dialect, the Ulster Scots idiom he heard in County Antrim, the language of the Irish poem Buile Shuibhne which he translated as Sweeney Astray (1983), the Gaelic Highlands and the oral Scots culture, the Old English as registered in the epic poem Beowulf, the English patrimony of linguistic imposition he could read in Wordsworth, Hopkins and Hardy, the American accents of Elizabeth Bishop, T.S Eliot, Robert Frost and Robert Lowell, as well as the estrangement suffered by the English language when possessed by poets such as Joseph Brosky, Iain Crichton Smith and Sorley Maclean, or by wonderful translators, whose works were well-known to Heaney, such as John D. Sinclair and Charles S. Singleton when they sweated on Dante Alighieri's Comedy. If you are a reader wanting to get this kind of music at the back of Heaney's ear, it is advisable that, as MacCaig said in one of his poems referring to MacDiarmid, you 'should observe / two minutes pandemonium'. 


\section{References}

Fazzini M (1989a) ‘Tre poesie di Seamus Heaney per Omar Galliani: “Anteo”, “Il rabdomante", "L'ammasso nordico" in O Galliani, Perle. Firenze: Gentili Arte Contemporanea.

Fazzini M (1989b) ‘Seamus Heaney, poeta archeologo'. Origini: rivista di-segno e poesia (no. 8).

Fazzini M (ed.) (2005) Alba Literaria: A History of Scottish Literature. Mestre: Amos Edizioni.

Glob P V (1969) The Bog People. Iron-Age Men Preserved. Translated by Robert BruceMitford. London: Faber and Faber.

Heaney S (1980a) Preoccupations. Selected Prose 1968-1978. London: Faber and Faber. Heaney S (1980b) Selected Poems 1965-1975. London: Faber and Faber.

Heaney S (1983) An Open Letter. Derry: Field Day Theatre Company.

Heaney S (1984) Station Island. London: Faber and Faber.

Heaney S (1986), 'Introduction' to Ross R J \& Hendry J (1986) Sorley Maclean. Critical Essays. Edinburgh: Scottish Academic Press.

Heaney S (1996) The Spirit Level. London: Faber and Faber.

Heaney S (2002) Finders Keepers. Selected Prose 1971-2001. London: Faber and Faber.

Heaney S (2008) Beowulf. An Illustrated Edition. New York/London: W.W. Norton.

Heaney S (2009) 'Introduction’ to The Testament of Cresseid \& Seven Fables. London: Faber and Faber. 
Livingstone D (1978) The Anvil's Undertone. Craighall: Ad.Donker.

MacCaig N (1990) Collected Poems: A New Edition. London: Chatto \& Windus.

MacCaig N (1995) L'equilibrista. Poesie scelte 1955-1990. A cura di Marco Fazzini; prefazione di Seamus Heaney; introduzione di Valerie Gillies. Grottammare: Stamperia dell'Arancio.

MacDiarmid H (2000) On a Raised Beach/Sopra un terrazzo marino. A cura di Marco Fazzini; con una poesia di Seamus Heaney. Venezia: Supernova.

Maclennan D (2001) Rock Paintings at Salem. Grahamstown: Graphics Services.

Maxwell D E S (1965) 'Landscape and Theme' in J Press (ed.) Commonwealth: Unity and Diversity within a Common Culture. London: Heinemann.

O’Driscoll D (2008) Stepping Stones. Interviews with Seamus Heaney. London: Faber and Faber.

Wylie D \& Mackenzie C (eds.) (2012) 'No Other World'. Essays on the life-work of Don Maclennan. Noordhoek: PrintMatters Heritage. 